\title{
Biodiversity of the microbial mat of the Garga hot spring
}

\author{
Alexey Sergeevich Rozanov ${ }^{1 *}$, Alla Victorovna Bryanskaya', Timofey Vladimirovich Ivanisenko ${ }^{1,2}$, \\ Tatyana Konstantinovna Malup ${ }^{1}$ and Sergey Evgenievich Peltek'
}

From Belyaev Conference

Novosibirsk, Russia. 07-10 August 2017

\begin{abstract}
Background: Microbial mats are a good model system for ecological and evolutionary analysis of microbial communities. There are more than 20 alkaline hot springs on the banks of the Barguzin river inflows. Water temperature reaches $75{ }^{\circ} \mathrm{C}$ and $\mathrm{pH}$ is usually 8.0-9.0. The formation of microbial mats is observed in all hot springs. Microbial communities of hot springs of the Baikal rift zone are poorly studied. Garga is the biggest hot spring in this area.

Results: In this study, we investigated bacterial and archaeal diversity of the Garga hot spring (Baikal rift zone, Russia) using $16 \mathrm{~S}$ rRNA metagenomic sequencing. We studied two types of microbial communities: (i) small white biofilms on rocks in the points with the highest temperature $\left(75^{\circ} \mathrm{C}\right)$ and (ii) continuous thick phototrophic microbial mats observed at temperatures below $70{ }^{\circ} \mathrm{C}$. Archaea (mainly Crenarchaeota; $19.8 \%$ of the total sequences) were detected only in the small biofilms. The high abundance of Archaea in the sample from hot springs of the Baikal rift zone supplemented our knowledge of the distribution of Archaea. Most archaeal sequences had low similarity to known Archaea. In the microbial mats, primary products were formed by cyanobacteria of the genus Leptolyngbya. Heterotrophic microorganisms were mostly represented by Actinobacteria and Proteobacteria in all studied samples of the microbial mats. Planctomycetes, Chloroflexi, and Chlorobi were abundant in the middle layer of the microbial mats, while heterotrophic microorganisms represented mostly by Firmicutes (Clostridia, strict anaerobes) dominated in the bottom part. Besides prokaryotes, we detect some species of Algae with help of detection their chloroplasts $16 \mathrm{~s}$ rRNA.

Conclusions: High abundance of Archaea in samples from hot springs of the Baikal rift zone supplemented our knowledge of the distribution of Archaea. Most archaeal sequences had low similarity to known Archaea. Metagenomic analysis of microbial communities of the microbial mat of Garga hot spring showed that the three studied points sampled at $70{ }^{\circ} \mathrm{C}, 55^{\circ} \mathrm{C}$, and $45{ }^{\circ} \mathrm{C}$ had similar species composition. Cyanobacteria of the genus Leptolyngbya dominated in the upper layer of the microbial mat. Chloroflexi and Chlorobi were less abundant and were mostly observed in the middle part of the microbial mat. We detected domains of heterotrophic organisms in high abundance (Proteobacteria, Firmicutes, Verrucomicrobia, Planctomicetes, Bacteroidetes, Actinobacteria, Thermi), according to metabolic properties of known relatives, which can form complete cycles of carbon, sulphur, and nitrogen in the microbial mat. The studied microbial mats evolved in early stages of biosphere formation. They can live autonomously, providing full cycles of substances and preventing live activity products poisoning.
\end{abstract}

Keywords: Garga, Metagenome, Bacterial mats, Microbial community, Hot springs

\footnotetext{
*Correspondence: sibiryak.n@gmail.com; rozanov@bionet.nsc.ru

${ }^{1}$ Federal Research Center Institute of Cytology and Genetics, the Siberian

Branch of the Russian Academy of Sciences, Novosibirsk, Russia

Full list of author information is available at the end of the article
} 


\section{Background}

Microorganisms are detected in various conditions in most places [1]. They are the most ancient inhabitants of the planet. Due to their high variability, they have adapted to almost all extreme environmental niches, including high-temperature conditions [2]. They exist mainly in extreme environments. Microbial mats, in most cases autotrophic, are usually benthic communities typically formed on solid substrates that use $\mathrm{CO}_{2}$ as the carbon source. They are considered analogues of fossil stromatolites found in geological strata formed 3.5 billion years ago [3].

Microbial mats are good model systems for ecological and evolutionary analysis of microbial communities. They are usually small and almost closed self-sustaining ecosystems that include cycles of basic chemical elements and food chains. Sharp and continually changing gradients of physicochemical and chemical conditions create a large number of ecological micro-niches with very heterogeneous environments. The typical layered structure of phototrophic microbial mats is formed under the influence of the gradient of sunlight energy and chemical conditions supported by the activity of microorganisms $[4,5]$. The most important function of phototrophic microorganisms in microbial mats is to absorb sunlight energy and $\mathrm{CO}_{2}$ to create organic material, including extracellular polymers [6]. Polymers forming extracellular matrices are very important for maintenance of microbial communities. They stabilize the sediments and the physical mat structure [7]. Organic material formed by primary producers is the basis for community food chains. It is converted by heterotrophic microorganisms of the community in various processes to produce energy and biomaterials [8].

There are several alkaline hot springs on the banks of the Barguzin river inflows. Water temperature reaches $75{ }^{\circ} \mathrm{C}$ and $\mathrm{pH}$ 8.0-9.0. The formation of microbial mats is observed in all hot springs [9]. Microbial communities of hot springs of the Baikal rift zone are poorly studied, especially using modern methods of molecular biology. In most cases, methods of microbiology were used to describe them. Only the communities of microbial mats of the Alla hot springs were described using molecular biology methods [10].

In this work, we studied a microbial mat detected in the Garga hot spring of the Baikal rift zone of the bank of the Garga River. The Garga hot spring differs from other hot springs of the Baikal rift zone, which have lower $\mathrm{pH}$ values (8.1). The spring comes to the surface as a single outlet, not a group of small sources like most hot springs of the Barguzin river valley. The microbial mat is formed on the slopes of the travertine dome. The thickness of the structured microbial mat is up to $7 \mathrm{~cm}$.

\section{Methods}

\section{Sampling}

Samples were taken from the Garga hot spring (Barguzin valley, East Barguzin fault, Baikal rift zone, Russia) on June 5-8, 2010. Samples of microbial communities for metagenomic studies were collected in sterile 50-ml Falcons and fixed with $96 \%$ ethanol. The samples were stored at $-72{ }^{\circ} \mathrm{C}$ in "Collection of biotechnological microorganisms as a source of novel promising objects for biotechnology and bioengineering of Federal Research Center Institute of Cytology and Genetics of the Siberian Branch of the RAS".

The spring is located on the slope on the western side of the Barguzin valley. It forms a carbonate "travertine" dome consisting of several terraces with the maximum thickness of $2.5 \mathrm{~m}$; terraces are 30 to $80 \mathrm{~cm}$ high [11, 12]. A thick cyanobacterial mat covers the travertine surface of the spring bank.

The sulphate-sodium water of the Garga hot spring has mineralization of $1 \mathrm{~g} / \mathrm{l} . \mathrm{SiO}_{2}$ content is $30 \mathrm{mg} / \mathrm{l}$; F, $11 \mathrm{mg} / \mathrm{l}$; the highest temperature, $77^{\circ} \mathrm{C}$; and $\mathrm{pH}, 8.1$. Microelement composition is dominated by $\mathrm{Li}, \mathrm{Rb}, \mathrm{Sr}$, $\mathrm{Ca}$, and $\mathrm{Ba}$ with lower amounts of Ge, Mo, and W [13]. Geology and hydrology of the spring were described in detail in $[11,14-16]$.

\section{DNA extraction}

DNA extraction was performed in September 2010. The sample was triturated in a sterile ceramic mortar if necessary. Approximately $300 \mu \mathrm{l}$ of sample suspension was added to Eppendorf tubes $(2 \mathrm{~mL})$. The suspension was centrifuged at $8000 \times \mathrm{g}$ for $10 \mathrm{~min}$. The pellet was re-suspended by pipetting in $500 \mu \mathrm{l}$ buffer containing 100mMol Tris- $\mathrm{HCl}, \mathrm{pH} 8,100 \mathrm{mMol}$ EDTA, $\mathrm{pH}-8.0$; $30 \mu \mathrm{l}$ of chloroform and $200 \mu \mathrm{l}$ of lysozyme $(50 \mathrm{mg} / \mathrm{ml})$ were added, and cells were incubated at $37{ }^{\circ} \mathrm{C}$ for $1 \mathrm{~h}$, with shaking at $5 \mathrm{~min}$ intervals, and with subsequent addition of $100 \mu \mathrm{l}$ 10\% SDS and $100 \mu \mathrm{l} 10 \%$ sarkosyl (Sigma). We performed three cycles of freezing in liquid nitrogen for $2 \mathrm{~min}$ and thawing for $5 \mathrm{~min}$ at $65^{\circ} \mathrm{C}$. Another freeze-thaw cycle was performed after addition of $100 \mu \mathrm{l}$ 10\% Polyvinylpyrrolidone (Sigma). Then $50 \mu \mathrm{l}$ of $2.5 \mathrm{M} \mathrm{CaCl}_{2}$ were added, and the suspension was incubated at $65^{\circ} \mathrm{C}$ for $10 \mathrm{~min}$ with occasional shaking. The supernatant was transferred to a sterile tube, and an equal volume of phenol/chloroform (1/1) was added to the tube. The tubes were vortexed for $2 \mathrm{~min}$ and centrifuged at $13,000 \times \mathrm{g}$ for $10 \mathrm{~min}$. The supernatant $(400 \mu \mathrm{l})$ was transferred to a new tube containing $100 \mu \mathrm{l} 10 \mathrm{M}$ $\mathrm{NH}_{4} \mathrm{Ac}$ and $1 \mathrm{ml}$ of $96 \%$ ethanol, incubated overnight at $-20{ }^{\circ} \mathrm{C}$ and centrifuged at $16,000 \times \mathrm{g}$ for $20 \mathrm{~min}$. The precipitate was washed with $70 \%$ ethanol, dried at room temperature and dissolved in water (mQ). 


\section{Library construction}

DNA extracted from the samples was used as a template for amplification of bacterial and archaeal 16S rRNA genes with universal primers: U341F (5'-CCTACGGGRS GCAGCAG-3') and U806R (5' - GGACTACNVGGG TWTCTAAT-3') [17, 18]. Reagents for PCR (DMSO, P CR buffer, polymerase, nucleotide triphosphates) were purchased from Agilent Technologies, USA. PCR mix $(50 \mu \mathrm{l})$ contained $1 \times$ herculase buffer, $10 \mu \mathrm{M}$ of each dNTPs, 10pmoles of forward and reverse primers, $100 \mathrm{ng}$ of DNA, and 2.5u of Herculase. The following amplification profile was used: $3 \mathrm{~min}$ at $95{ }^{\circ} \mathrm{C} ; 6$ cycles of $15 \mathrm{~s}$ at $95^{\circ} \mathrm{C}, 15 \mathrm{~s}$ at $50{ }^{\circ} \mathrm{C}$, and $60 \mathrm{~s}$ at $72{ }^{\circ} \mathrm{C} ; 35$ cycles of $10 \mathrm{~s}$ at $95{ }^{\circ} \mathrm{C}, 10 \mathrm{~s}$ at $55^{\circ} \mathrm{C}$, and $60 \mathrm{~s}$ at $72{ }^{\circ} \mathrm{C}$; and an additional elongation phase of $5 \mathrm{~min}$ at $72{ }^{\circ} \mathrm{C}$. Amplified products were purified using commercial kits (Fermentas, Lithuania) and used for an additional PCR reaction with primers containing marker sequences designed for the 2x250bp read lengths sequencing protocol, according to the manufacturer's instructions (Illumina, USA). The following re-amplification profile was used: 3 min at $95{ }^{\circ} \mathrm{C}$; 4 cycles of $15 \mathrm{~s}$ at $95{ }^{\circ} \mathrm{C}, 15 \mathrm{~s}$ at $56^{\circ} \mathrm{C}$, and $60 \mathrm{~s}$ at $72{ }^{\circ} \mathrm{C}$; 15 cycles of $10 \mathrm{~s}$ at $95^{\circ} \mathrm{C}, 10 \mathrm{~s}$ at $55^{\circ} \mathrm{C}$, and $30 \mathrm{~s}$ at $72{ }^{\circ} \mathrm{C}$; and an additional elongation phase of $5 \mathrm{~min}$ at $72{ }^{\circ} \mathrm{C}$. The obtained PCR fragments for the different samples were mixed and purified by electrophoresis in 1,5\% agarose gel. Libraries were constructed in October 2012.

\section{NGS sequencing}

NGS sequencing of the variable V3-V4 regions of the $16 \mathrm{~S}$ rRNA gene was performed on MiSeq (Illumina) using the MiSeq reagent kit v.2 (Illumina). Library preparation was done with Nextera DNA sample prep (Illumina). Sequencing was performed at the Faculty of Bioengineering and Bioinformatics, Lomonosov Moscow State University. Sequencing was performed in April 2013.

\section{Metagenomic data processing}

16S rRNA reads (a total of 232,310 reads) were filtered, denoised and processed with a QIIME pipeline v1.9.1 [19]. All sequences were clustered, de novo chimera checked and quality filtered using USEARCH (Ultra-fast sequence analysis) tool v5.2.236 [20] against the Gold database (http://drive5.com/uchime/gold.fa). Sequences tagged as non-chimeric were combined and sorted by abundance. Then, operational taxonomic units (OTU) picking was performed; each non-chimeric read was assigned to a specific OTU identifier. A representative sequence for each OTU was queried against the GREENGENES database v13_8 [21] using UCLUST v1.2.22q program (http://www.drive5.com/uclust/downloads1_2_22q.html) from QIIME. The represented OTU was submitted in NCBI (KY767848-KY767913,
KY552127-KY552260, KY552040-KY552126, KY551710-

KY551870, KY551585-KY551709, KY551871-KY552039, KY497789-KY497909, KX979916-KX980027).

\section{Phylogenetic tree construction}

Reference sequences of microorganisms' $16 \mathrm{~S}$ rRNA genes were obtained from the NCBI database (refseq_rna). Phylogenetic analysis was performed using MEGA (molecular evolutionary genetics analysis; http:// www.megasoftware.net/index.html.), version 6.0 [22]. Distance matrices were calculated according to the Kimura two-parameter model [23]. Phylogenetic trees were inferred using the neighbour-joining method [24]. Bootstrap values were determined based on 1000 replications.

\section{Results and discussion}

The Garga hot spring (Fig. 1) has pH 8.1, unlike most hot springs of this region that have $\mathrm{pH}$ closer to 9.0. Microbial mats (Fig. 2) in the Garga hot spring formed in the stream from the exit to the surface to the confluence with the Garga river (the inflow of the Barguzin river).

\section{The description of the Garga hot spring microbial mats and the selected samples}

Sampling scheme is shown in Fig. 2 d.

GA1 point was located in the area of the thermal water exit. The temperature at the time of sampling was $74{ }^{\circ} \mathrm{C}$. A small white biofilms placed on the rocks (sample Ga1).

GA2 point (Fig. 2a) was located in the thermal stream with the temperature about $70{ }^{\circ} \mathrm{C}$. At the edge of the stream, we observed a yellow gelatinous microbial mat. This mat extended from this point to the point of confluence into the river. The mat was thick $(4 \mathrm{~cm})$, very tight and layered. The top layer of the mat (sample Ga2_verh) was a thin $(2 \mathrm{~mm})$ film strongly linked to the underlying layer. The middle layer was less dense. The thickness of that layer was $2 \mathrm{~cm}$. The bottom layer was white, gelatinous and linked to the substrate. The layer thickness was $1 \mathrm{~cm}$.

Microbial mat in the GA3 sampling point $\sim 55{ }^{\circ} \mathrm{C}$ (Fig. $2 \mathrm{~b}, \mathrm{c})$ was dense, greenish, and $2-3 \mathrm{~cm}$ thick. The top layer (sample Ga3_verh) was a yellow-green film approximately $2 \mathrm{~mm}$ thick, hardly separable from the middle layer. The middle layer (sample Ga3_sred) was membranous, gelatinous and whitish-green. The upper two layers were similar in structure to the microbial mat of point GA2, but had a more intensive green colour. The bottom layer of the mat (sample Ga3_niz) was white, attached to the substrate, with a thickness of about $1 \mathrm{~cm}$. The profile picture of the microbial mat at that point is shown in Fig. 2c. 


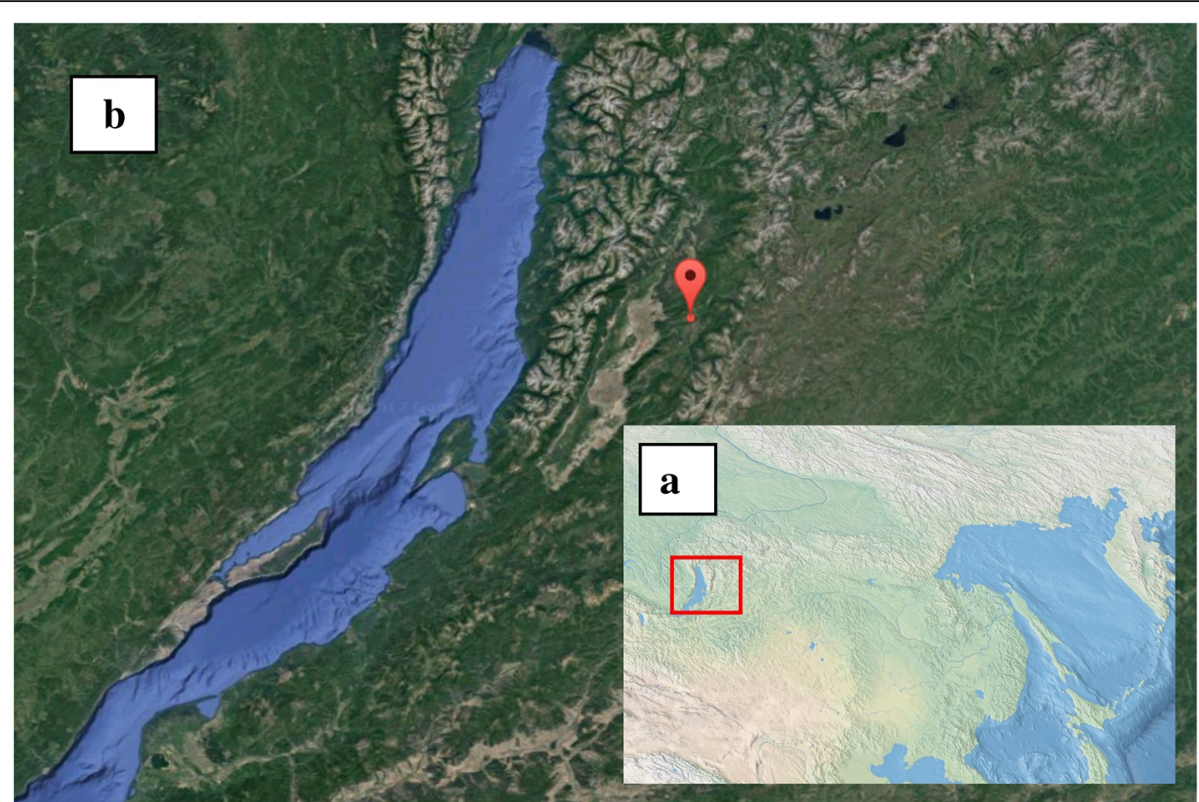

Fig. 1 a, Eastern Siberia; b, Eastern Baikal, Barguzin Valley, satellite photo. Red cross marks the location of the Garga hot spring (54 $\left.14^{\circ} 3.72^{\prime \prime} \mathrm{N}, 110^{\circ} 59^{\prime \prime} 38.4^{\prime \prime} \mathrm{E}\right)$
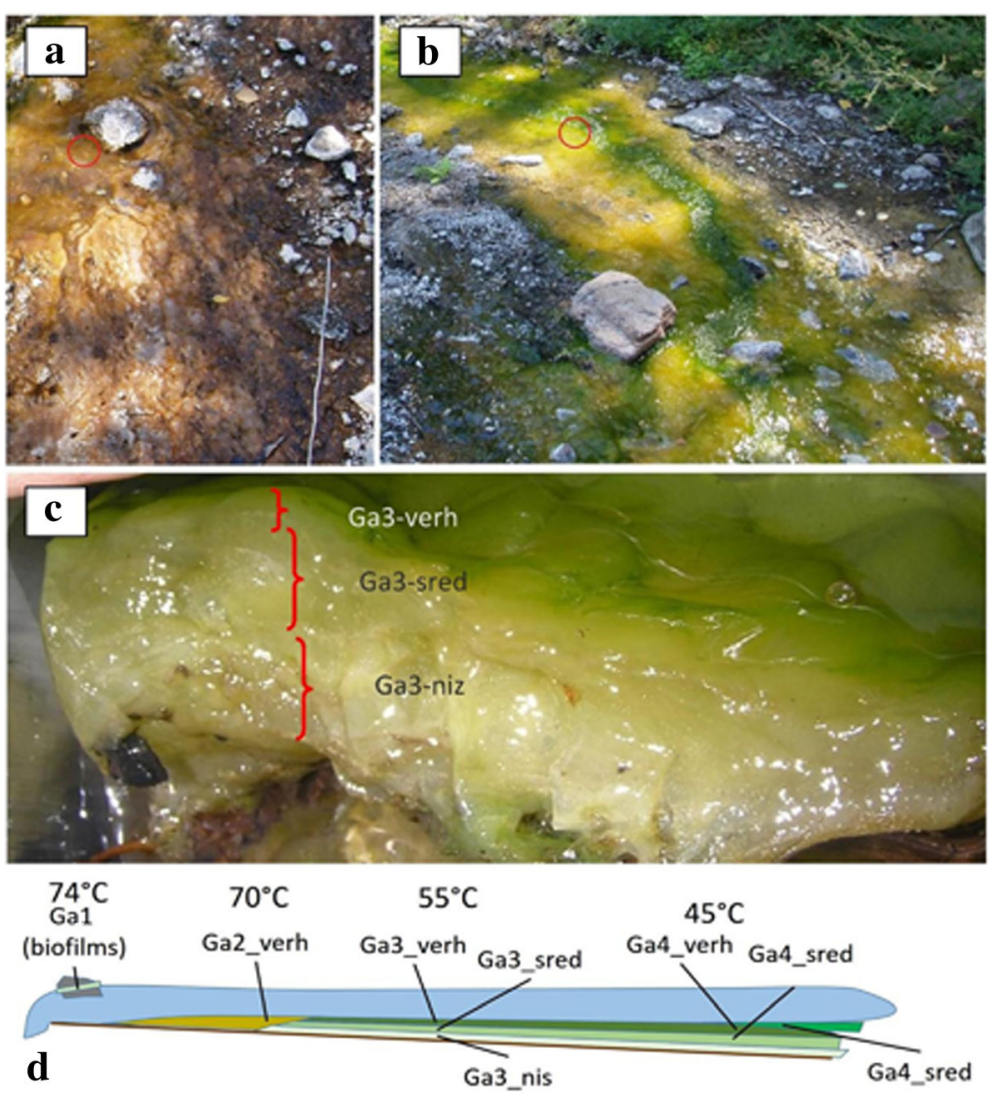

Fig. 2 Microbial mats of the Garga hot spring. a, microbial mat of the upper reaches of the spring; red circle, GA2 sampling point. b, microbial mat of the middle reaches; red circle, GA3 sampling point. c, layers of the GA3 sample. $\mathbf{d}$, sampling scheme 
The mat in the sampling point GA4 $45{ }^{\circ} \mathrm{C}$. The upper two layers (samples Ga4_verh and Ga4_sred) were similar to the microbial mat of point GA3. The bottom layer of the mat at that point was a relatively thick "film"-skin coloured, with a thickness of 0.3$0.5 \mathrm{~cm}$. In addition to the structured microbial mats at this point, we also revealed friable bright green films (sample Ga4_zel).

After bioinformatics processing of metagenomic data, we obtained from 13,000 to $34,00016 \mathrm{~S}$ rRNA sequences for each of the eight studied samples. The total number of sequences was 222,201. Sequences were divided into operational taxonomic units (OTUs) individually for each sample; $5 \%$ to $15 \%$ of sequences in each sample could not be identified. Figure 3 shows the number of various microorganism types. Data were submitted in NCBI (KY767848-KY767913, KY552127-KY552260, KY 552040-KY552126, KY551710-KY551870, KY551585-KY 551709, KY551871-KY552039, KY497789-KY497909, and KX979916-KX980027). FASTQ files are in supplement.

\section{Microbial communities of the sampling point with highest temperatures (GA1)}

In the hottest point of the Garga hot spring (GA1) $74^{\circ}$

$\mathrm{C}$, biofilms were observed on the border with the air.
Figure 3 shows the relative abundance of various microorganisms in this point (Ga1). Phototrophic microorganisms accounted for only about $\sim 6 \%$ of the total sample, while Firmicutes (Bacilli) (21.9\%) and Proteobacteria (21.4\%) were the most abundant, the former represented mostly by the mesophilic Bacillus pumilus [25]. Approximately $3 \%$ of sequences belonged to the genus Staphylococcus.

\section{Archaea}

Archaea constituted $19.8 \%$ of the total number of sequences, which is the highest percentage for the Baikal rift zone obtained to date. Archaea were not detected in other sampling points except Ga3-sred (0.04\%). Only OTU-1, OTU-34 and OTU-72 belonging to Crenarchaeota were closely related to any cultivated archaea (Fig. 4). The remaining archaeal sequences obtained in our study had no close similarity to any known microorganisms, as well as in most cases to sequences of uncultivated specimens.

Crenarchaeota was the most abundant archaeal phylum in our sample. OTU-1 (7.9\% of the total archaeal sample) was very similar (99\%) to Thermoproteus uzonensis [26]. This anaerobic archaeon was isolated from the Uzon volcano caldera in the Kamchatka peninsula. Its optimum growth was observed at $\mathrm{pH} 5.5$, while

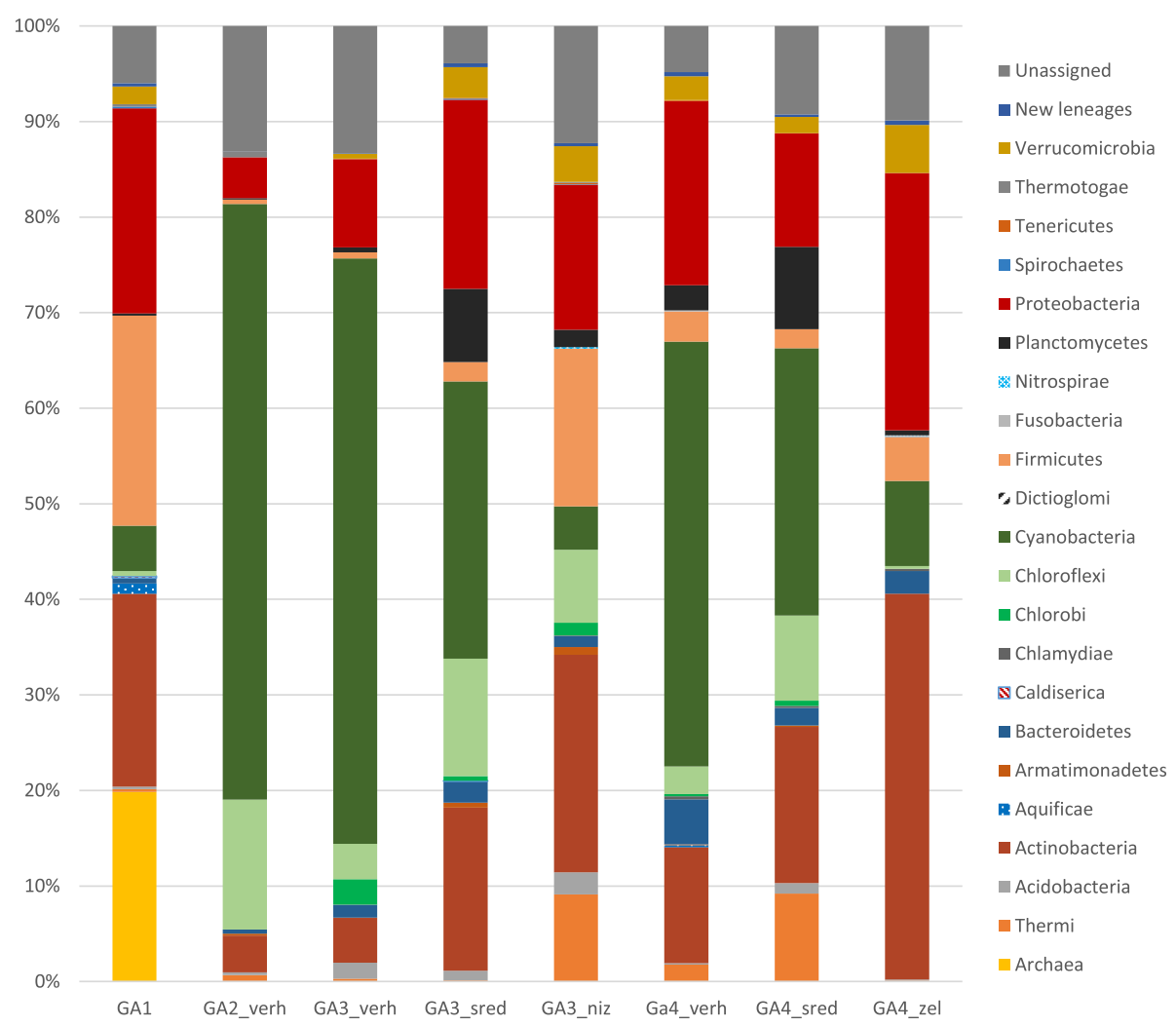

Fig. 3 The percentage of various microorganism groups in the samples 


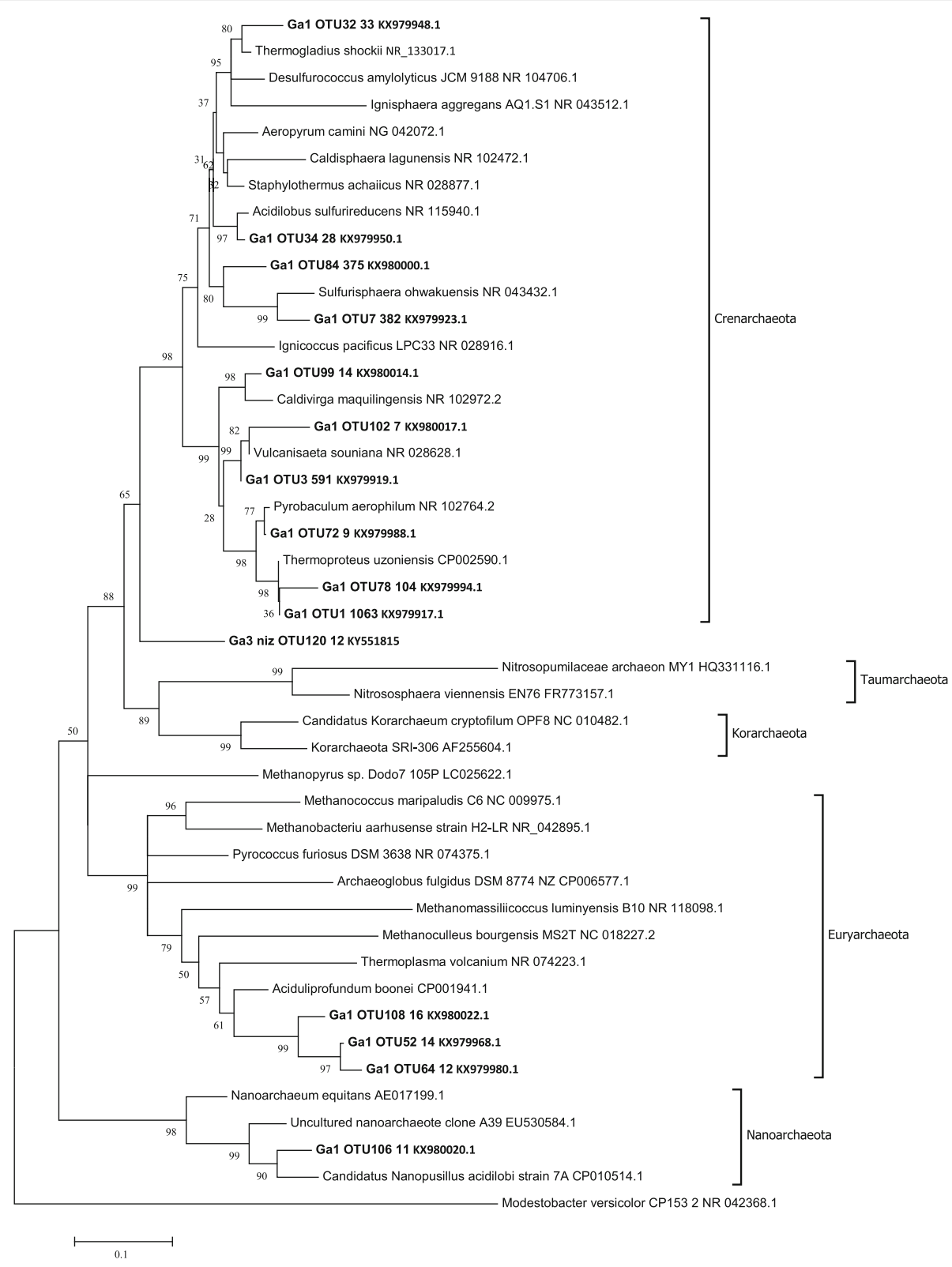

Fig. 4 Maximum likelihood tree of Archaea obtained in this study. Bootstrap values were calculated for 200 alternative trees; scale, number of substitutions per site. OTU names include sample name, OTU number, and the number of sequences belonging to this group

the Garga hot spring has pH 8.3. OTU-3 (4.4\%) had 99\% sequence similarity to the crenarchaeote Vulcanisaeta souniana isolated from several hot spring areas in eastern Japan, which is also anaerobic and acidophilic [27]. OTU-7 and OTU-84 (2.8\% each) had no close sequence similarity to any known species. Metagenomic sequences with the highest degree of similarity (96\%) for OTU-7 were found in hot springs in Japan [28] and Thailand (NCBI/nr), while for OTU-84, 97\% similar sequences were obtained from hot springs in Iceland [29]. OTU-78 $(0.7 \%)$ had only $92 \%$ sequence similarity to uncultured microorganisms. Another 9 archaean OTUs were less abundant and had less than 95\% sequence similarity to known microorganisms, which means that hot springs of the Baikal region contain many new species of Archaea.

\section{Microbial communities in the microbial mats of Garga hot spring Cyanobacteria}

Cyanobacteria (Fig. 5) dominated in the microbial mat of the Garga hot spring community (points GA2, GA3, and GA4). They produce much of the organic matter and form the structure of the microbial mat. Leptolyngbya 


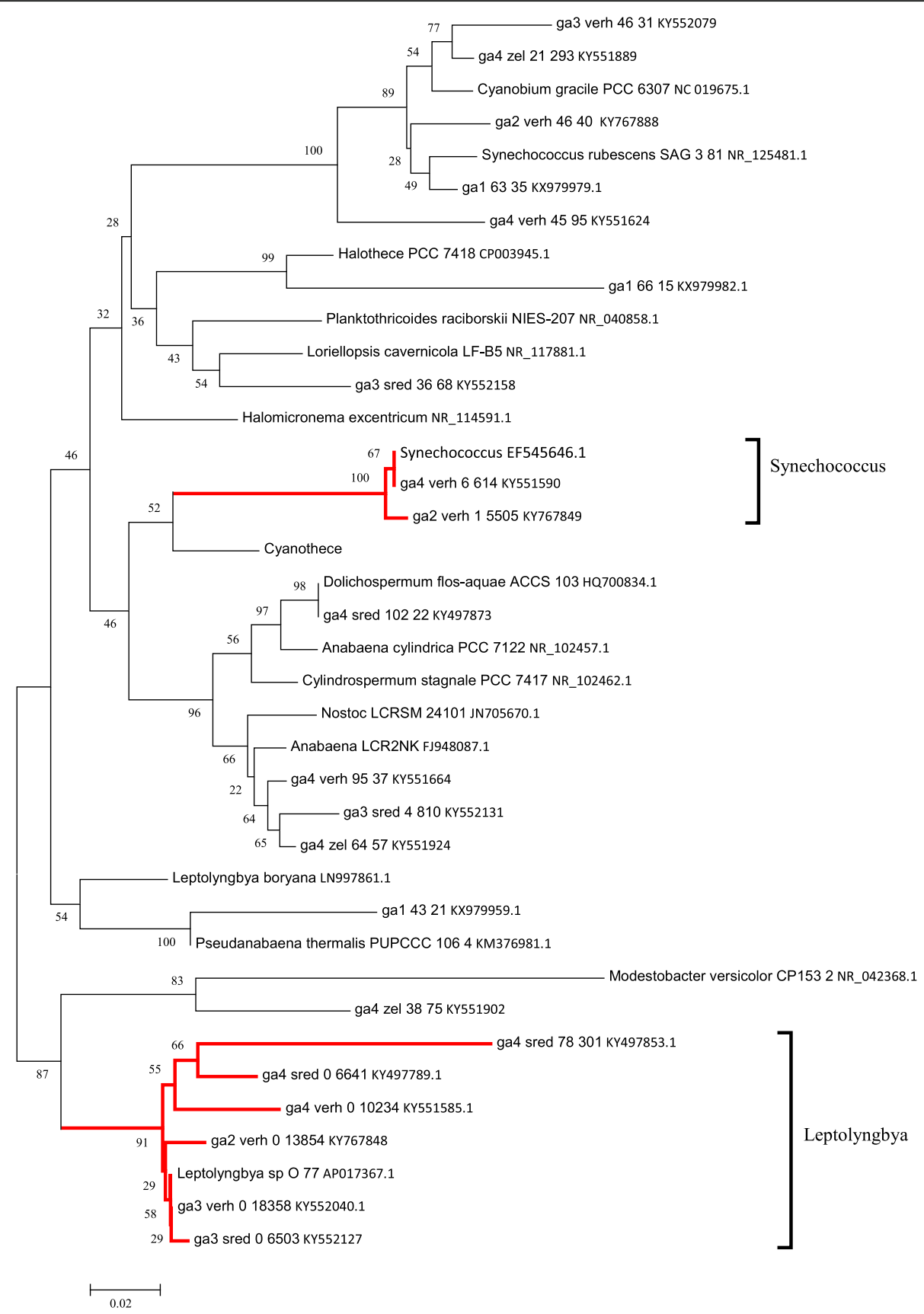

Fig. 5 Maximum likelihood phylogenetic tree of cyanobacterial OTUs found in the Garga hot spring. Bootstrap values were calculated for 200 alternative trees; scale, number of substitutions per site. OTU names include sample name, OTU number, and the number of sequences belonging to this group. Branches including highly abundant OTUs are shown in red

accounted for the majority of cyanobacterial sequences (> $70 \%)$ in all microbial mat samples. All sequences of Leptolyngbya were most closely related to that of Leptolyngbya sp. O-77 isolated from Japanese hot springs [30]. Representatives of the genus Leptolyngbya were detected in hot springs in Romania [31], Teng Chong (China) [32], Neuquen (Argentina) [33], and Yellowstone (USA) [34]. They were prevalent in microbial mats growing in alkaline fluids in northeast Australia [35], East Africa [36], and Greenland [37], as well as in certain hot springs in the Baikal region [10].

Representatives of the genera Synechococcus (OTU-1) were also abundant in Ga2-verh, and Nostoc (OTU-4), in Ga3-sred. OTU-1 (17.5\%) had 99\% sequence similarity to the organisms found in the Alla and Uro hot springs (NCBI/nr) near Baikal. OTU-4 (9.0\%) was 96\% similar to 
a cyanobacterium isolated from a microbial mat in a cement factory in India (NCBI/nr KF746950, KF746951). The genera Synechococcus and Nostoc are widespread in microbial mats of most hot springs. Synechococcus is a cosmopolitan genus of cyanobacteria found in marine, freshwater, thermal, terrestrial and subaerial habitats [38, 39]. This genus is the most polyphyletic group of cyanobacteria and in the future a possible splitting of the Synechococcus lineages into different genera [40].

Algal (Stramenopiles) 16S rRNA sequence were also detected in the microbial mat. Algae probably provided bright green colour to the mat at point GA4. Stramenopiles were found in various marine symbiotic communities, e.g., inside the sponge Tethya californiana [41]. The photosynthetic stramenopile Ochrophyta forms a highly diverse clade within Heterokonta, a clade that also included a number of heterotrophic lineages such as plant moulds and aquatic pseudofungi. The majority of published molecular phylogenetic analyses indicate that the photosynthetic and non-photosynthetic stramenopiles form a monophyletic taxon [42]. The earliest fossil remains (Palaeovaucheria; Xanthophyceae) suggest that the photosynthetic stramenopiles appeared 1000 million years ago (Ma) [43].

\section{Chloroflexi and Chlorobi of the Garga hot spring microbial mats}

Although layers formed by Chloroflexi and Chlorobi were not detected, they were identified in all our samples. They accounted for $>10 \%$ of the total number of sequences in the Ga2-verh and Ga3-sred samples and were most closely related to the organisms from the same rift zone, the Alla and Uro hot springs [10]. Chloroflexi are facultative anaerobes, anoxigenic phototrophs or lithotrophs [44, 45]. Chlorobi are anaerobic and anoxic phototrophs that can use sulfide and thiosulfate as electron acceptors [46]. We found two groups of Chloroflexi formed by the genera Chloroflexus and Anaerolineae, as well as one group comprised of various Chlorobi (Fig. 6). Representatives of the Chloroflexus group were closely related to the well-known Chloroflexus aurantiacus $[45,47]$. The rest of the algae had less than $83 \%$ sequence similarity to known microorganisms (NCBI/refseq_rna). Chloroflexi and Chlorobi

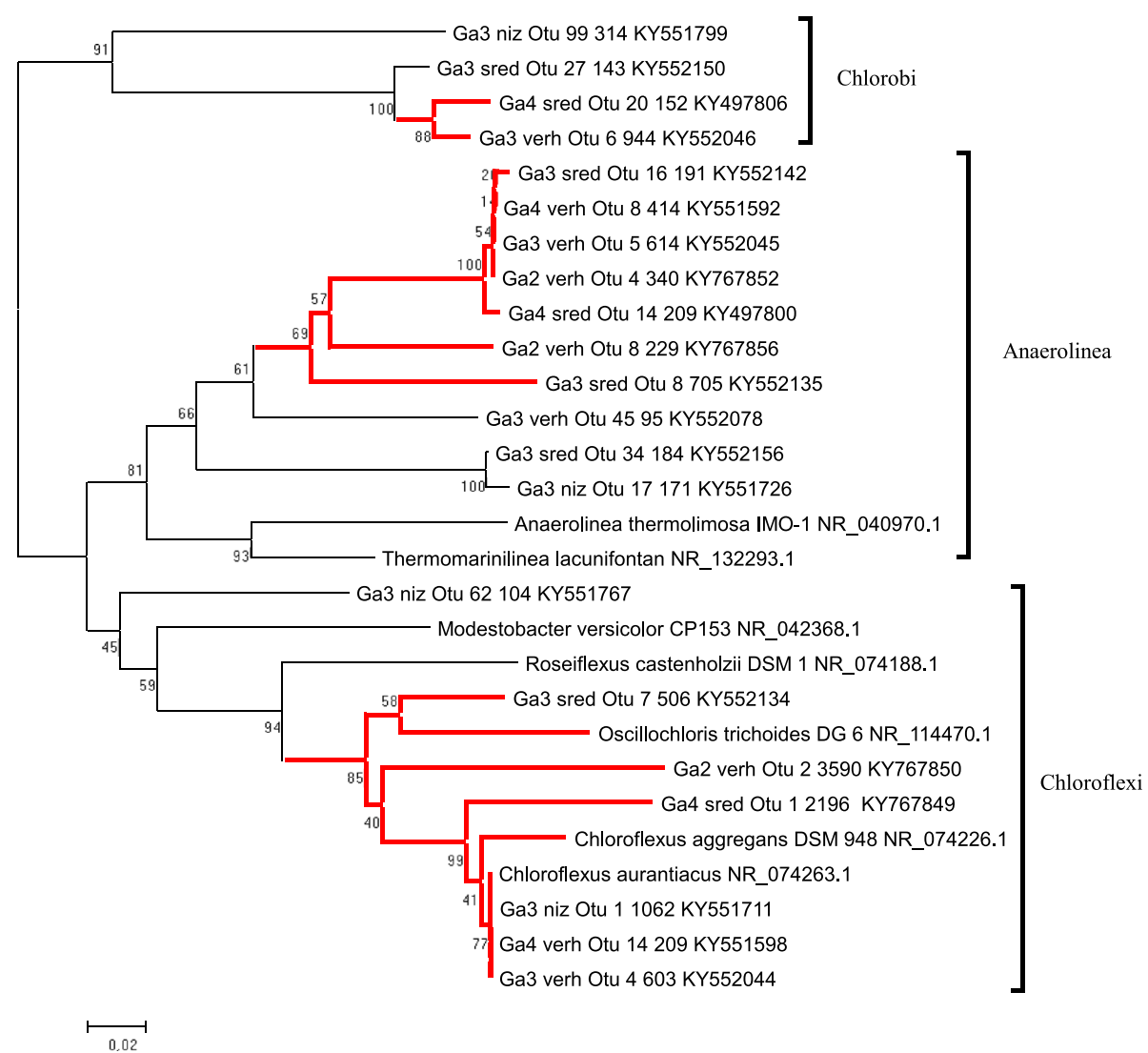

Fig. 6 Maximum likelihood phylogenic tree for OTU representative sequences of anoxygenic phototrophs found in the Garga hot spring. Bootstrap values were calculated for 200 alternative trees; scale, number of substitutions per site. OTU names include sample name, OTU number, and the number of sequences belonging to this group. Branches including highly abundant OTUs are shown in red 
are widespread in microbial mats in hot springs in Japan [48], Yellowstone (USA) [49], Kamchatka [50], Thailand [51], Tibet [52], and Andes [53].

\section{Heterotrophic microorganisms of the Garga hot spring microbial mat}

Proteobacteria and Actinobacteria prevailed among heterotrophic microorganisms in all samples of the Garga hot spring microbial mat. Actinobacteria were mainly represented by two orders, Acidimicrobiales and Actinomycetales. Diversity of Proteobacteria was higher and was mainly represented by the orders Rhizobiales, Rhodobacterales, Rhodospirillales, Sphingomonadales, Burkholderiales, Pseudomonadales, and Xanthomonadales.

Proteobacteria were found in almost all studied hot springs, including Andes, Colombia [54], South Africa [55], Kamchatka (Mutnovsky, caldera Uzon) [56], Malaysia [57], Tengchong (China) [32], Romania [31], Spain [58], and Yellowstone (USA) [59].

Actinobacteria were found in microbial communities in hot springs of Kamchatka (Russia), Tengchong (China), Nevada (USA) [60], Bor-Khlueng (Thailand) [61], Japan [62], and many others; however, they never prevailed.

Actinobacteria are the most numerous organisms of soil and aquatic ecosystems $[63,64]$. They play an important role in geochemical cycles. They are gut symbionts [65] and animal pathogens [66]. Actinobacteria are interesting for biotechnology as destructors of plant residues [18] and producers of a large number of secondary metabolites [67]. Thermobifida fusca and Acidothermus cellulolyticus 11B [68] are the most famous among thermophilic Actinobacteria due to the presence of cellulolytic enzyme complex. Nevertheless, information on the biodiversity and role of Actinobacteria in geothermal habitats is scarce $[69,70]$.

The middle and bottom layers of the Garga hot spring microbial mat consist of significant amounts of other types of heterotrophs except for Proteobacteria and Actinobacteria. In the middle layer of the microbial mat in the Ga-3-sred and Ga-2-sred samples, Planctomycetes accounted for $7 \%$ to $9 \%$ of the total number of sequences. Verrucomicrobia formed up to $5 \%$ in GA3 (except Ga-3-verh) and GA4. Planctomycetes and Verrucomicrobia were reported for many geothermal springs $[31,57,71]$.

Firmicutes (mainly Clostridia) accounted for $14.6 \%$ of the total number of sequences in the Ga-3-niz layer of the GA3 point (Fig. 3). Clostridia are strong anaerobes. The sequences of this class were not found in other samples. The thermophilic Clostridia are best known for their ability to degrade lignocellulose. They form cellulosomes, enzymes united in a macromolecule via interaction of special domains (Cohesines and Dockerines) and providing strong binding of subunits [72].

Thermi is another type of bacteria that was abundant in the microbial mat (samples Ga-3-niz and Ga-4-sred). Bacteria of this type are known as thermophiles and are distributed in hot springs everywhere [73].

\section{Metabolism of Garga hot spring microbial mat}

Metabolic pathways in the Garga hot spring microbial mat are based on the interaction of autotrophic and

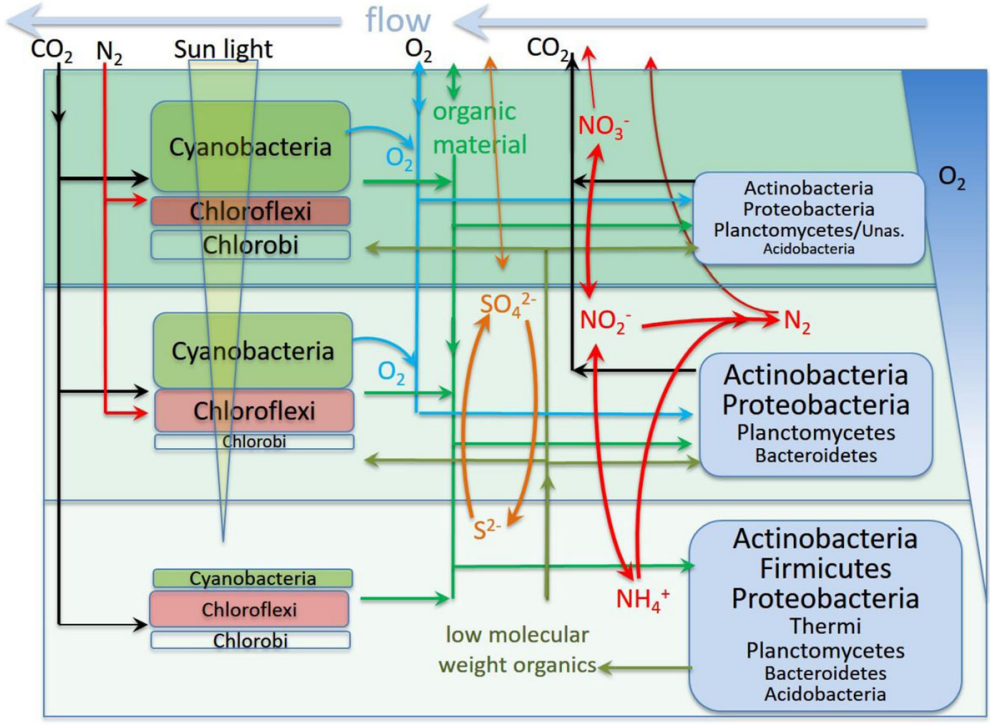

Fig. 7 A scheme of the Garga hot spring microbial mat, including main groups of microorganisms and the pathways of substance and energy flow. The most abundant organism types are highlighted by bold and large print: green, cyanobacteria; pink, Chloroflexi; blue, heterotrophic bacteria 
heterotrophic microorganisms and on the redox gradient. The analysed microbial mat can be divided into three layers (Fig. 7). Photosynthetic activity is the highest in the upper layer, while in the middle layer, the amount of sunlight decreases, as does the exchange rate of low molecular weight substances with water flow. As the rate of photosynthesis decreases, diversity and abundance of heterotrophic microorganisms increases. We observed an increase in the proportion of Chloroflexi in this layer, which may be associated with low sunlight intensity and the presence of redox gradient. No separate layer of anoxic phototrophic bacteria was observed, which may be associated with the high speed of surface water flow and smooth gradient redox.

The bottom layer of the microbial mat is the destruction zone. The oxygen does not penetrate here and is not produced by photosynthesis as evidenced by the presence of obligately anaerobic Clostridia in the bottom layer (Ga-3-niz). Phototrophic microorganisms and aerobic bacteria badly adapted for anaerobic conditions die in this layer. The organic material is destroyed to low molecular weight organics.

Anaerobic fermentation is the main mechanism for conversion of organic substances in the bottom layer of the microbial mat. Low molecular weight products formed by fermentation are moved into the upper layers, where they are aerobically oxidized and provide extra food for microorganisms living there. The concentration of inorganic substances in the water of the spring is too low, primarily of reduced sulphur compounds, so the probability that lithotrophic transformation pathways dominate in the Garga hot spring microbial mat is relatively low [13]. However, it should be noted that sulphur may be accumulated in different forms depending on the redox state, so a sulphur cycle may exist in the microbial mat. The catalysis of the sulphur redox conversion may be carried out by Proteobacteria, Firmicutes [33], Chloroflexi, and Chlorobi [74, 75].

According to geochemical analysis, the water of the spring does not contain nitrogen compounds, so nitrogen fixation is the only possible source of nitrogen for the community. We found many species capable of nitrogen fixation (both oxygenic and anoxygenic phototrophes, some representatives of Proteobacteria and Actinobacteria). The presence of Planctomycetes indicates active redox transformations of nitrogen compounds in the mat. They can oxidize ammonium produced in the bottom layer of the microbial mat, while subsequent reactions result in formation of $\mathrm{N} 2$ and removal of nitrogen from the cycle [76].

\section{Conclusion}

High abundance of Archaea in samples from hot springs of the Baikal rift zone supplemented our knowledge of the distribution of Archaea. Most archaeal sequences had low similarity to known Archaea. We detected archaeal sequences that accounted for $19.8 \%$ of the total number of sequences in the Gal sample. It is first time when such amounts of Archaea were detected in samples from hot springs of the Baikal rift zone. We were the first to demonstrate abundance of Archaea in the hot springs of the Baikal rift zone. They could be delivered at the Ga1 point from the depth by the flow, while mesophilic bacteria could be from the surrounding microbial communities. The most abundant Archaea belonged to Thermoproteus uzonensis and Vulcanisaeta souniana. Those Archaea are anaerobic and acidophilic. Most detected archaeal OTUs did not have high similarity to known archaeal species.

Metagenomic analysis of microbial communities of the microbial mat of Garga hot spring showed that the three studied points sampled at $70{ }^{\circ} \mathrm{C}, 55{ }^{\circ} \mathrm{C}$, and $45{ }^{\circ} \mathrm{C}$ had similar species composition. Cyanobacteria of the genus Leptolyngbya dominated in the upper layer of the microbial mat, accounting for over $60 \%$ of sequences, and considering that Cyanobacteria have large cells, their biomass share can exceed $90 \%$. Chloroflexi and Chlorobi were less abundant and were mostly observed in the middle part of the microbial mat. Based on metabolic analysis, we suggest that there are complete cycles of carbon, sulphur, and nitrogen in the community. The carbon cycle starts with the formation of phototrophic biomass in the top layer with subsequent decomposition in the bottom layers to alcohols and organic acids, which are used by microorganisms in upper layers. Cycles of sulphur and nitrogen are complete due to the presence of redox gradient. The sulphur cycle can be considered a closed one; the outflow of sulphur compounds is carried out with the flow of water. Nitrogen compounds are removed from the cycle by diffusion and the anamnox reaction $\left(\mathrm{NH}_{4}^{+}+\mathrm{NO}_{2}^{-}=\mathrm{N}_{2}+2 \mathrm{H}_{2} \mathrm{O}\right)$ performed by Planctomycetes. Microbial mats evolved in early stages of biosphere formation. They can be considered a model of the systems that existed before the origin of plants. Our study demonstrates that microbial mats that evolved in early stages of biosphere formation could live autonomously, providing full cycles of elements and preventing poisoning by their own by-products.

Current thermal microbial mats are isolated from each other by mesopilic environments, and so may provide important insights into microbial evolution. Eukaryotes do not have significant effects on such communities because they are not adapted to high temperatures.

In addition to the Garga hot spring, there are other hot springs in the Baikal region, the microbial communities of which were poorly studied by modern genetic methods. This is one of the first studies on the detailed composition of a microbial mat from the Baikal area. 


\section{Acknowledgments}

We are grateful to Dr. Sergei Zhmodik., and Dr. Elena Lazareva, from IGM SB RAS for support the expedition to the Garga hot spring.

\section{Funding}

This work was supported by the Federal Agency of Scientific Organizations via ICG SB RAS project \# 0324-2017-0003.

Publication costs were funded by the Federal Agency of Scientific Organizations via ICG SB RAS project \# 0324-2017-0003.

\section{Availability of data and materials}

All datasets supporting the conclusions of this article uploaded on NCBI. The represented OTU was submitted in NCBI (KY767848-KY767913, KY552127-KY552260 KY552040-KY552126, KY551710-KY551870, KY551585-KY551709, KY551871-KY552039, KY497789-KY497909, KX979916-KX980027)

\section{About this supplement}

This article has been published as part of BMC Evolutionary Biology Volume 17 Supplement 2, 2017: Selected articles from Belyaev Conference 2017 evolutionary biology. The full contents of the supplement are available online at https://bmcevolbiol.biomedcentral.com/articles/supplements/ volume-17-supplement-2.

\section{Authors' contributions}

Conception and design of the study: ASR, SEP. Samples collection: AVB, ASR. Samples processing: ASR, TKM. Material Data analysis: TVI, ASR. Manuscrip drafting: ASR. Manuscript revision for critical intellectual content: ASR, AVB. All authors read and approved the final manuscript.

\section{Ethics approval and consent to participate}

Not applicable.

\section{Consent for publication}

Not applicable.

\section{Competing interests}

The authors declare that they have no competing interests.

\section{Publisher's Note}

Springer Nature remains neutral with regard to jurisdictional claims in published maps and institutional affiliations.

\section{Author details}

${ }^{1}$ Federal Research Center Institute of Cytology and Genetics, the Siberian Branch of the Russian Academy of Sciences, Novosibirsk, Russia. ${ }^{2}$ Novosibirsk State University, Novosibirsk, Russia.

\section{Published: 28 December 2017}

\section{References}

1. Whitman WB, Coleman DC, Wiebe WJ. Prokaryotes: the unseen majority. Proc Natl Acad Sci U S A. 1998;95:6578-83.

2. Miroshnichenko ML, Bonch-Osmolovskaya EA. Recent developments in the thermophilic microbiology of deep-sea hydrothermal vents. Extremophiles. 2006;10:85-96

3. Sergeev VN, Gerasimenko LM, Zavarzin GA. The Proterozoic history and present state of cyanobacteria. Microbiology. 2002;71:623-37.

4. Vangemerden H. Microbial mats - a joint venture. Mar Geol. 1993:113:3-25.

5. Zavarzin GA. Diversity of cyano-bacterial mats. Fossil Recent Biofilms. 2003: $141-50$

6. De Philippis R, Vincenzini M. Exocellular polysaccharides from cyanobacteria and their possible applications. FEMS Microbiol Rev. 1998;22:151-75.

7. Grant J, Gust G. Prediction of coastal sediment stability from photopigment content of mats of purple sulfur bacteria. Nature. 1987;330:244-6.

8. Pomeroy LR, Williams PJI, Azam F, Hobbie JE. The microbial loop. Oceanography. 2007;20:28-33.

9. Namsaraev BB, Barkhutova DD, Danilova EV, Dagurova OP, Namsaraev ZB, Tsetseg B, Oyuntsetseg A. Structure and functioning of microbial community of mineral springs in Central Asia. Mongolian J Biol Sci Russia. 2003:37-42.
10. Gaisin VA, Kalashnikov AM, Sukhacheva MV, Namsaraev ZB, Barhutova DD, Gorlenko VM, Kuznetsov BB. Filamentous anoxygenic phototrophic bacteria from cyanobacterial mats of Alla hot springs (Barguzin Valley, Russia). Extremophiles. 2015;19:1067-76.

11. Plyusnin AM, Suzdalnitsky AP, Adushinov AA, Mironov AG. Features of formation of travertines from carbonic and nitrogen thermal waters in the zone of the Baikal rift. Geology Geophysics Russia. 2000:564-70.

12. Tatarinov AV, Yalovik LI, Namsaraev ZB, Plyusnin AM, Konstantinova KK, Zhmodik SM. The role of bacterial mats in petrogenesis and the formation of ore minerals of travertines of nitrogen hydrotherms of the Baikal rift zone. Rep Acad Sci. 2005:678-81.

13. Lazareva EB, Zhmodik SM, Petrova IV, Kolmogorov UP, Fedorin MA, Bryansk $A V$, Taran OP. Investigation of the distribution of elements between the cyanobacterial community and the carbonate construction of the thermal source by the RFA SI method. Surface. X-ray, synchrotron and neutron studies. 2012;6:77-85.

14. Borisenko IM, Zaman LV. Mineral waters of Buryat ASSR. Ulan-Ude: Buryat publishing house. 1978; 162 with

15. Sklyarov EV, Fedorovsky VS, Sklyarova OA, Skovitina TM, Danilova SE, Orlova LA, Ukhova NN. Hydrothermal activity in the Baikal rift zone: hot springs and deposition products of paleotherms. Rep Russian Acad Sci. 2007:412(2): 257-61.

16. Lomonosov IS. Geochemistry and formation of hydrotherms of the Baikal rift zone. Novosibirsk: Science; 1974. p. 166.

17. Baker GC, Smith JJ, Cowan DA. Review and re-analysis of domain-specific 16S primers. J Microbiol Methods. 2003;55:541-55.

18. Wang Y, Qian PY. Conservative fragments in bacterial 165 rRNA genes and primer design for 165 ribosomal DNA amplicons in metagenomic studies. PLoS One. 2009:4:10-e7401.

19. Caporaso JG, Kuczynski J, Stombaugh J, Bittinger K, Bushman FD, Costello EK, Fierer N, Pena AG, Goodrich JK, Gordon JI, Huttley GA, Kelley ST, Knights D, Koenig JE, Ley RE, Lozupone CA, McDonald D, Muegge BD, Pirrung M, Reeder J, Sevinsky JR, Tumbaugh PJ, Walters WA, Widmann J, Yatsunenko T, Zaneveld J, Knight R. QIIME allows analysis of high-throughput community sequencing data. Nat Methods. 2010;7:335-6.

20. Edgar RC. Search and clustering orders of magnitude faster than BLAST. Bioinformatics. 2010;26:2460-1.

21. DeSantis TZ, Hugenholtz P, Larsen N, Rojas M, Brodie EL, Keller K, Huber T, Dalevi D, Hu P, Andersen GL. Greengenes, a chimera-checked 165 rRNA gene database and workbench compatible with ARB. Appl Environ Microbiol. 2006;72:5069-72.

22. Tamura K, Stecher G, Peterson D, Filipski A, Kumar S. MEGA6: molecular evolutionary genetics analysis version 6.0. Mol Biol Evol. 2013;30:2725-9.

23. Kimura M. A simple method for estimating evolutionary rates of base substitutions through comparative studies of nucleotide sequences. J Mol Evol. 1980;16:111-20.

24. Saitou N, Nei M. The neighbor-joining method: a new method for reconstructing phylogenetic trees. Mol Biol Evol. 1987:4:406-25.

25. Kunst F, Ogasawara N, Moszer I, Albertini AM, Alloni G, Azevedo V, Bertero MG, Bessieres P, Bolotin A, Borchert S, Borriss R, Boursier L, Brans A, Braun M, Brignell SC, Bron S, Brouillet S, Bruschi CV, Caldwell B, Capuano V, Carter NM, Choi SK, Codani JJ, Connerton IF, Cummings NJ, Daniel RA, Denizot F, Devine KM, Dusterhoft A, Ehrlich SD, Emmerson PT, Entian KD, Errington J, Fabret C, Ferrari E, Foulger D, Fritz C, Fujita M, Fujita Y, Fuma S, Galizzi A, Galleron N, Ghim SY, Glaser P, Goffeau A, Golightly EJ, Grandi G, Guiseppi G, Guy BJ, Haga K, Haiech J, Harwood CR, Henaut A, Hilbert H, Holsappel S, Hosono S, Hullo MF, Itaya M, Jones L, Joris B, Karamata D, Kasahara Y, KlaerrBlanchard M, Klein C, Kobayashi Y, Koetter P, Koningstein G, Krogh S, Kumano M, Kurita K, Lapidus A, Lardinois S, Lauber J, Lazarevic V, Lee SM, Levine A, Liu H, Masuda S, Mauel C, Medique C, Medina N, Mellado RP, Mizuno M, Moestl D, Nakai S, Noback M, Noone D, Oreilly M, Ogawa K, Ogiwara A, Oudega B, Park SH, Parro V, Pohl TM, Portetelle D, Porwollik S, Prescott AM, Presecan E, Pujic P, Purnelle B, Rapoport G, Rey M, Reynolds S, Rieger M, Rivolta C, Rocha E, Roche B, Rose M, Sadaie Y, Sato T, Scanlan E, Schleich S, Schroeter R, Scoffone F, Sekiguchi J, Sekowska A, Seror SJ, Serror P, Shin BS, Soldo B, Sorokin A, Tacconi E, Takagi T, Takahashi H, Takemaru K, Takeuchi M, Tamakoshi A, Tanaka T, Terpstra P, Tognoni A, Tosato $V$, Uchiyama S, Vandenbol M, Vannier F, Vassarotti A, Viari A, Wambutt $R$, Wedler E, Wedler $H$, Weitzenegger T, Winters $P$, Wipat A, Yamamoto H, Yamane K, Yasumoto K, Yata K, Yoshida K, Yoshikawa HF, Zumstein E, Yoshikawa H, Danchin A. The complete 
genome sequence of the gram-positive bacterium Bacillus subtilis. Nature. 1997;390:249-56.

26. Mardanov AV, Gumerov VM, Beletsky AV, Prokofeva MI, Bonch-Osmolovskaya EA, Ravin NV, Skryabin KG. Complete genome sequence of the Thermoacidophilic Crenarchaeon Thermoproteus uzoniensis 768-20. J Bacteriol. 2011;193:3156-7.

27. Itoh T, Suzuki Kl, Nakase T. Vulcanisaeta distributa gen. Nov., sp. nov., and Vulcanisaeta souniana sp. nov., novel hyperthermophilic, rod-shaped crenarchaeotes isolated from hot springs in Japan. Int J Syst Evol Microbiol. 2002;52(4):1097-104.

28. Kimura H, Mori K, Tashiro T, Kato K, Yamanaka T, Ishibashi J, Hanada S. Culture-independent estimation of optimal and maximum growth temperatures of Archaea in subsurface habitats based on the $\mathrm{G}$ plus $\mathrm{C}$ content in 16S rRNA gene sequences. Geomicrobiol J. 2010;27:114-22.

29. Mirete S, de Figueras CG, Gonzalez-Pastor JE. Diversity of Archaea in Icelandic hot springs based on $16 \mathrm{~S}$ rRNA and chaperonin genes. FEMS Microbiol Ecol. 2011;77:165-75.

30. Nakamori H, Yatabe T, Yoon KS, Ogo S. Purification and characterization of an oxygen-evolving photosystem II from Leptolyngbya sp strain 0-77. J Biosci Bioeng. 2014;118:119-24.

31. Coman C, Druga B, Hegedus A, Sicora C, Dragos N. Archaeal and bacterial diversity in two hot spring microbial mats from a geothermal region in Romania. Extremophiles. 2013;17:523-34.

32. Pagaling E, Grant WD, Cowan DA, Jones BE, Ma Y, Ventosa A, Heaphy S. Bacterial and archaeal diversity in two hot spring microbial mats from the geothermal region of Tengchong, China. Extremophiles. 2012;16:607-18.

33. Sofia Urbieta M, Gonzalez-Toril E, Aguilera Bazan A, Alejandra Giaveno M, Donati E. Comparison of the microbial communities of hot springs waters and the microbial biofilms in the acidic geothermal area of Copahue (Neuqun, Argentina). Extremophiles. 2015;19:437-50.

34. Lau E, Nash CZ, Vogler DR, Cullings K. W. Molecular diversity of cyanobacteria inhabiting coniform structures and surrounding mat in a Yellowstone hot spring. Astrobiology. 2005;5:83-92.

35. McGregor GB, Rasmussen JP. Cyanobacterial composition of microbial mats from an Australian thermal spring: a polyphasic evaluation. FEMS Microbiol Ecol. 2008;63:23-35.

36. Dadheech PK, Glöckner G, Casper P, Kotut K, Mazzoni CJ, Mbedi S, Krienitz L. Cyanobacterial diversity in the hot spring, pelagic and benthic habitats of a tropical soda lake. FEMS Microbiol Ecol. 2008;85:389-401.

37. Roeselers G, Norris TB, Castenholz RW, Rysgaard S, Glud R, Kuhl NM, Muyzer G. Diversity of phototrophic bacteria in microbial mats from Arctic hot springs (Greenland). Environ Microbiol. 2007:9:26-38.

38. Callieri C, Coci M, Corno G, Macek M, Modenutti B, Balseiro E, Bertoni R. Phylogenetic diversity of nonmarine picocyanobacteria. FEMS Microbiol Ecol. 2013;85:293-301.

39. Melendrez MC, Lange RK, Cohan FM, Ward DM. Influence of molecular resolution on sequence-based discovery of ecological diversity among Synechococcus populations in an alkaline siliceous hot spring microbial mat. Appl Environ Microbiol. 2011;77:1359-67.

40. Dvořák $P$, Casamatta DA, Poulíčková A, Hašler P, Ondřej V, Sanges R. Synechococcus: 3 billion years of global dominance. Mol Ecol. 2014;23:5538-51.

41. Sipkema D, Blanch HW. Spatial distribution of bacteria associated with the marine sponge Tethya Californiana. Mar Biol. 2010;157:627-38.

42. Brown JW, Sorhannus U. A molecular genetic timescale for the diversification of autotrophic Stramenopiles (Ochrophyta): substantive underestimation of putative fossil ages. PLoS One. 2010;5

43. German TN. Organicheskii mir milliard let nazad (Organic World a Billion Years Ago). Nauka Leningrad. 1990.

44. Collins AM, Xin Y, Blankenship RE. Pigment organization in the photosynthetic apparatus of Roseiflexus castenholzii. Biochimica Et Biophysica Acta Bioenergetics. 1787;2009:1050-6.

45. Pierson BK, Castenholz RW. A phototrophic gliding filamentous bacterium of hot springs, Chloroflexus aurantiacus, gen. And sp. nov. Arch Microbiol. 1974:5:24.

46. Frigaard NU, Chew AGM, Li H, Maresca J, Bryant DA. Chlorobium tepidum: insights into the structure, physiology, and metabolism of a green sulfur bacterium derived from the complete genome sequence. Photosynth Res. 2003;78:93-117.

47. Tang KH, Barry K, Chertkov O, Dalin E, Han CS, Hauser LJ, Honchak BM, Karbach LE, Land ML, Lapidus A, Larimer FW, Mikhailova N, Pitluck S, Pierson BK, Blankenship RE. Complete genome sequence of the filamentous anoxygenic phototrophic bacterium Chloroflexus aurantiacus. BMC Genomics. 2011;12:1-334.
48. Everroad RC, Otaki H, Matsuura K, Haruta S. Diversification of bacterial community composition along a temperature gradient at a thermal spring. Microbes Environ. 2012;27:374-81.

49. Boomer SM, Noll KL, Geesey GG, Dutton BE. Formation of multilayered photosynthetic biofilms in an alkaline thermal spring in Yellowstone National Park, Wyoming. Appl Environ Microbiol. 2009;75:2464-75.

50. Akimov VN, Podosokorskaya OA, Shlyapnikov MG, Gal'chenko VF. Dominant phylotypes in the 165 rRNA gene clone libraries from bacterial mats of the Uzon caldera (Kamchatka, Russia) hydrothermal springs. Microbiology. 2013; 82:721-7.

51. Portillo MC, Sririn V, Kanoksilapatham W, Gonzalez J. M. Differential microbial communities in hot spring mats from Western Thailand. Extremophiles. 2009;13:321-31

52. Lau MCY, Aitchison JC, Pointing SB. Bacterial community composition in thermophilic microbial mats from five hot springs in central Tibet. Extremophiles. 2009;13:139-49.

53. Engel AS, Johnson LR, Porter ML. Arsenite oxidase gene diversity among Chloroflexi and Proteobacteria from el Tatio geyser field, Chile. FEMS Microbiol Ecol. 2013;83:745-56.

54. Javier Jimenez D, Andreote FD, Chaves D, Salvador Montana J, Osorio-Forero C, Junca $\mathrm{H}$, Mercedes Zambrano M, Baena S. Structural and functional insights from the Metagenome of an acidic hot spring microbial Planktonic Community in the Colombian Andes. PLoS One. 2012;7:12-e52069.

55. Tekere M, Loetter A, Olivier J, Jonker N, Venter S. Metagenomic analysis of bacterial diversity of Siloam hot water spring, Limpopo, South Africa. Afr J Biotechnol. 2011;10:18005-12.

56. Wemheuer B, Taube R, Akyol P, Wemheuer F, Daniel R. Microbial diversity and biochemical potential encoded by thermal spring Metagenomes derived from the Kamchatka peninsula, Archaea. Int Microbiol J. 2013;

57. Chan CS, Chan KG, Tay YL, Chua YH, Goh KM. Diversity of thermophiles in a Malaysian hot spring determined using $16 \mathrm{~S}$ rRNA and shotgun metagenome sequencing. Front Microbiol. 2015;6

58. Lopez-Lopez O, Knapik K, Cerdan ME, Gonzalez-Siso MI. Metagenomics of an alkaline hot spring in Galicia (Spain): microbial diversity analysis and screening for novel Lipolytic enzymes. Front Microbiol. 2015;6

59. Meyer-Dombard DR, Shock EL, Amend JP. Archaeal and bacterial communities in geochemically diverse hot springs of Yellowstone National Park, USA. Geobiology. 2005:3:211-27.

60. Song Z, Zhi X, Li W, Jiang H, Zhang C, Dong H. Actinobacterial diversity in Hot Springs in Tengchong (China), Kamchatka (Russia), and Nevada (USA). Geomicrobiol J. 2009;26:256-63.

61. Kanokratana P, Chanapan S, Pootanakit K, Eurwilaichitr L. Diversity and abundance of bacteria and Archaea in the Bor Khlueng hot spring in Thailand. J Basic Microbiol. 2004;44:430-44.

62. Iino T, Mori K, Uchino Y, Nakagawa T, Harayama S, Suzuki Kl. Ignavibacterium album gen. nov, sp nov., a moderately thermophilic anaerobic bacterium isolated from microbial mats at a terrestrial hot spring and proposal of Ignavibacteria classis nov., for a novel lineage at the periphery of green sulfur bacteria. Int J Syst Evol Microbiol. 2010;60:1376-82

63. Daniel R. The soil metagenome - a rich resource for the discovery of novel natural products. Curr Opin Biotechnol. 2004;15:199-204.

64. Holmfeldt K, Dziallas C, Titelman J, Pohlmann K, Grossart HP, Riemann L. Diversity and abundance of freshwater actinobacteria along environmental gradients in the brackish northern Baltic Sea. Environ Microbiol. 2009;11: 2042-54.

65. Gill SR, Pop M, DeBoy RT, Eckburg PB, Turnbaugh PJ, Samuel BS, Gordon J, Relman DA, Fraser-Liggett CM, Nelson KE. Metagenomic analysis of the human distal gut microbiome. Science. 2006;312:1355-9.

66. Trujillo ME, Goodfellow M. Numerical phenetic classification of clinically significant aerobic sporoactinomycetes and related organisms. Anton Leeuw Int J Gen Mol Microbiol. 2003;84:39-68.

67. Wang C, Dong D, Wang H, Mueller K, Qin Y, Wang H, Wu W. Metagenomic analysis of microbial consortia enriched from compost: new insights into the role of Actinobacteria in lignocellulose decomposition. Biotechnology Biofuels. 2016;9

68. Lykidis A, Mavromatis K, Ivanova N, Anderson I, Land M, DiBartolo G, Martinez M, Lapidus A, Lucas S, Copeland A, Richardson P, Wilson DB, Kyrpides N. Genome sequence and analysis of the soil cellulolytic actinomycete Thermobifida fusca YX. J Bacteriol. 2007;189:2477-86.

69. Valverde A, Tuffin M, Cowan DA. Biogeography of bacterial communities in hot springs: a focus on the actinobacteria. Extremophiles. 2012;16:669-79. 
70. Shivlata L, Satyanarayana T. Thermophilic and alkaliphilic Actinobacteria: biology and potential applications. Front Microbiol. 2015;6

71. Nishiyama M, Yamamoto S, Kurosawa N. Microbial community analysis of a coastal hot spring in Kagoshima, Japan, using molecular- and culture-based approaches. J Microbiol. 2013;51:413-22.

72. Lamed R, Bayer EA. The cellulosome of clostridium-thermocellum. Adv Appl Microbiol. 1988;33:1-46.

73. Hugenholtz P, Pitulle C, Hershberger KL, Pace NR. Novel division level bacterial diversity in a Yellowstone hot spring. J Bacteriol. 1998;180:366-76.

74. Gregersen LH, Bryant DA, Frigaard NU. Mechanisms and evolution of oxidative sulfur metabolism in green sulfur bacteria. Front Microbiol. 2011;2

75. Bryant DA, Liu Z, Li T, Zhao F, Costas AMG, Klatt CG, Ward DM, Frigaard NU, Overmann J. Comparative and functional genomics of anoxygenic green bacteria from the taxa Chlorobi, Chloroflexi, and Acidobacteria. Springer Netherlands Functional genomics and evolution of photosynthetic systems. 2012;47:102

76. Schmidt I, Sliekers O, Schmid M, Cirpus I, Strous M, Bock E, Kuenen JG, Jetten MSM. Aerobic and anaerobic ammonia oxidizing bacteria competitors or natural partners. FEMS Microbiol Ecol. 2002;39:175-81.

Submit your next manuscript to BioMed Central and we will help you at every step:

- We accept pre-submission inquiries

- Our selector tool helps you to find the most relevant journal

- We provide round the clock customer support

- Convenient online submission

- Thorough peer review

- Inclusion in PubMed and all major indexing services

- Maximum visibility for your research

Submit your manuscript at www.biomedcentral.com/submit
Biomed Central 